\title{
8. The great roadmap charade: Electoral issues in post-coup Fiji
}

\section{Jon Fraenkel}

Electoral issues were to figure prominently in the wake of Fiji's 2006 coup - as instruments in the ideological justification of the military takeover; as internationally required stepping stones on the 'roadmap' back to democracy; and as predominant features of the interim government's vision for social transformation. The coup-makers and their supporters justified the seizure of power on the grounds that the May 2006 election had been marred by ethnically biased ballot-rigging; that the preparations of the Elections Office had been gravely mismanaged; that the constitution had been violated; and that Qarase's Soqosoqo Duavata ni Lewenivanua (SDL) party had abused its incumbent position in order to secure victory. Over the longer run, weaknesses in Fiji's electoral system were blamed for generating ethnic polarization since independence and for fostering an insular political control over the indigenous population by way of churches and chiefs. Only a wholesale reform of electoral laws - including the abolition of communal electorates - it was argued, would enable Fiji to chart its way to a multiracial future and definitively eliminate the coup cycle.

This chapter reviews the post-2006 coup controversies about the timetable for a return to democracy, about obstacles to holding fresh elections, and about the way electoral factors influenced Fiji's domestic politics. Analysing how electoral issues were negotiated provides a curious but useful way to view the way the events during the 18 months after the Fiji coup were played out, both domestically and internationally. It also suggests some important lessons about unintended consequences of standard Commonwealth and United Nations responses to countries that have witnessed coups, and the dangers associated with commonly promoted avenues for re-engagement.

\section{The authoritarian preference}

In his takeover speech on 5 December 2006, military commander Voreqe Bainimarama declared that 'when the country is stable and the Electoral Rolls and other machineries of Elections have been properly reviewed and amended, elections will be held'. ${ }^{1}$ Consistency with the constitution was claimed - despite a maelstrom of breaches - by indicating an intention to return to the polls once 'a proper census and electoral system' were in place. This was a vague commitment, and not one that gained much prominence in the tumultuous early days after the coup. Disdain for electoral democracy had been an important part of the commander's message over the preceding years. Upholding the 'rule of 
law' had figured centrally, but democracy had been dismissed as a mere 'numbers game', and the troubles of Fiji blamed squarely on 'politicians'. Bainimarama regularly played up the significance of the fact that the Republic of Fiji Military Forces (RFMF) had initially put Qarase's government into office back in July 2000, so that he could depict the prime minister as a disobedient subordinate who had defied orders. The commander consistently downplayed the fact that Qarase had won two elections - in 2001 and then again in 2006 - to distract from the Prime Minister's claim of something greater than a military mandate.

That commitment to the 'rule of law' could be extolled while electoral democracy was disparaged seemed curious. After all, the constitution specified that the government be democratically elected, and Fiji's judges had in the past found unelected regimes illegal. Yet perhaps this was not quite as strange as it at first sight appeared. Bainimarama was a military man, and within the RFMF rigid obedience to top-down authority was a pivotal element in the command structure, while accountability to the rank-and-file was non-existent. Armies are seldom democratic.

There were also strong Fijian antecedents for such a mixed position. Prominent mid-twentieth century Fijian politicians such as Ratu Sir Lala Sukuna - himself a dedicated military man - had deep misgivings about the suitability of democracy for Fiji. ${ }^{2}$ Ethnic Fijians only gained the vote in 1963, 34 years after the Fiji Indians. Until then, the council of chiefs had controlled which of their number sat on the legislative council, with the approval of the governor. The military had shown its antipathy towards electoral democracy in 1987, when it first overthrew a government. In March 2001, the RFMF had opposed elections as a way out of the impasse generated by the 2000 coup after the Court of Appeal had judged Qarase's first government to be illegal.

In the early days after the 2006 coup, that authoritarian preference was given free rein. Prime Minister Qarase and his cabinet were stood down, parliament was dissolved, and the Secretary General to Parliament and the Supervisor of Elections were dismissed. The President, Ratu Josefa Iloilo, was sidelined (although he was restored to office in January 2007). The assault on Fiji's core representational institutions was also pressed further and deeper: The Great Council of Chiefs (GCC - Bose Levu Vakaturaga) was forbidden from sitting after it defied the commander's demands: It was subsequently restructured and politically transformed under the impetus of presidential decrees. ${ }^{3}$ Soon, the Chief Executive Officers (CEOs) and other top officials in the ministries; the boards of the state-owned councils; and, by mid-2008, even quasi-private sector companies like Fijian Holdings Ltd were being purged and replaced by those who indicated their loyalty to the new order. If there was to be a return to democracy, it was destined to come to a thoroughly reconfigured polity. The commander and his allies hoped that their revolution would tear Fijians away 
from the influence of pastors and chiefs and that, with time, they might come to cherish the new order.

\section{Roadmap to engagement}

Post-coup statements about forthcoming elections initially acquired an inconsistent and rhetorical flavour, reflecting the regime's uncertainties about its own future. After he was elevated to the post of interim prime minister on 5 December 2006, semi-retired army camp physician Dr Jona Senilagakali said he was not sure when an election would be held: 'Democracy might be all right for Australia and New Zealand but [it is] certainly not all right for Fiji', he said, echoing the familiar post-1987 coup objections to democracy as a 'foreign flower' ${ }^{4}$ When Bainimarama handed power back to the 86-year old president on 4 January 2007 and took for himself the interim prime ministerial post, Ratu Josefa Iloilo's speech enjoined the RFMF commander rather vaguely to 'take our country to democratic elections after an advanced electoral office and systems are in place and the political and economic conditions are conducive to the holding of such elections'. 5 The President's military minder, Rupeni Nacewa, said polls might be five years away, but that this was 'merely a timeframe'. 6 The commander wanted the timing of the election to depend on the completion of his 'clean-up campaign', so that corruption might be thoroughly cleansed from Fiji beforehand. Conversely, Fiji's provincial chiefs, the Methodist Church and the SDL urged an early election as the way forward, having by early 2007 already despaired of restoring the deposed government. ${ }^{7}$

Interim government statements about the timing of the anticipated election soon came to reflect commitments made to the Commonwealth, European Union (EU) and Pacific Islands Forum (PIF). Former Speaker of the House, Ratu Epeli Nailatikau, played a key behind-the-scenes role in the early days after the coup liaising with the supranational organizations on behalf of the regime, as did the former CEO in the foreign affairs ministry, Isikeli Mataitoga. Commonwealth rules stipulated 'up to two years as the time frame for the restoration of democracy where the institutions are not in place to permit the holding of elections within, say, a maximum of six months' ${ }^{\prime}{ }^{8}$ That such institutions were not in place, and had not been in place at the time of the May 2006 poll, became a pivotal plank of the coup-supporters' international diplomacy. In a document released in early January 2007, Fiji Human Rights Commission (FHRC) director Shaista Shameem argued that the 2006 elections had violated the constitution because a census of population had not been drawn up beforehand and because the Constituency Boundaries Commission had not revised district boundaries prior to the polls. ${ }^{9}$ These claims were almost universally ridiculed by those familiar with the political situation in pre-coup Fiji, but they were echoed by Commodore Bainimarama. ${ }^{10}$ 
For their part, the Commonwealth and the EU were eager to engage with the post-coup Fiji government, and privately indicated their frustration with the belligerent stances of Australia and New Zealand. Canberra and Wellington were, in early 2007, still bristling at the collapse of their pre-coup efforts to broker a settlement between Bainimarama and Qarase and avert the coup. During the countdown to the military takeover, personal insults had been traded between Bainimarama and Australian Foreign Minister Alexander Downer. The commander condemned Australia, the UK and the USA for having allegedly sought to provoke a pre-coup mutiny against his authority at the Queen Elizabeth Barracks. After the coup, the Australian and New Zealand High Commissions were focal points for the post-coup military administration's claims of overseas-orchestrated destabilization, perceptions that culminated in the expulsion of New Zealand High Commissioner Michael Green in June 2007. For Australia and New Zealand, engagement under the auspices of the PIF thus became preferable to re-warming direct bilateral dealings. Since most new antipodean aid was immediately suspended in the wake of the coup ${ }^{11}$, the familiar pattern of condition-based restoration of grant assistance in the wake of Fiji coups focused on paying for things that could plausibly be viewed as encouraging a restoration of democracy.

For the EU and the Commonwealth, the PIF was also the convenient brokerage point. The Commonwealth Secretariat had a well-established tradition of interaction with the Pacific's major regional organization, and funded several of its key positions. EU adjustment to new World Trade Organization (WTO) rules had come to entail support for Pacific regional trade deals. EU assistance was particularly important to Fiji, since a F\$350 million grant to assist the rehabilitation of the Fiji sugar industry after the end of EU price subsidies had been agreed. However, article 96 of the EU's 2000 Cotonou Agreement made provision for a suspension of aid in cases of violation of human rights, democratic principles or the rule of law. The 2006 coup thus threatened possible cancellation of that grant assistance. In specifying conditions for continued payments, the EU, like the PIF, said it wanted to see an election before March 2009. ${ }^{12}$

In early 2007, the PIF engaged an Eminent Persons Group (EPG) to visit Fiji. Vanuatu Deputy Prime Minister Sato Kilman led a team comprising Samoan minister Faumuina Liuga, former PNG Chief Justice Sir Arnold Amet, and retired Australian Defence Force chief, General Peter Cosgrove. ${ }^{13}$ The EPG report called on the interim government 'to commit without delay to a roadmap with measurable milestones which includes ... a firm timeframe for a national election (in the EPG's view this should be between eighteen months and two years, if not sooner)' ${ }^{14}$ The interim government responded by proposing a 36-month timetable, and requesting \$53.5 million for conducting a 12-15 month census of population, a Constituency Boundaries Commission (another 6 months), and other preparations for elections including setting up an electronic voter 
registration system, conducting a voter education program and administering the elections (another 12 months). ${ }^{15}$ Time was also needed, Bainimarama said, to facilitate economic recovery, to clean up corruption and to review the constitution. 16

\section{The real danger of elections}

Although the need for institutional reform was now agreed by both sides as the justification for some delay before fresh elections, this was not the real reason. The Commonwealth's Millbrook principles encouraged an emphasis on charting a 'roadmap' through various technical obstacles to holding elections, but most informed observers in Fiji knew that an election, if held, would produce a similar result to that of May 2006. ${ }^{17}$ The maths were simple. Bainimarama's coup had overthrown a government that had obtained 80 per cent of the votes of ethnic Fijians only eight months earlier. By 2007, ethnic Fijians comprised 57 per cent of the population. If anything, indigenous Fijian attitudes had hardened since the 2006 election, as they had seen their politicians, chiefs and church leaders ridiculed, chastised and challenged by the military commander. So an election in 2009 would be likely to return Qarase's SDL or some similarly oriented ethnic Fijian-backed party, although such an outcome was anathema to the commander.

With Labour leader Mahendra Chaudhry as finance minister in the interim cabinet, the military-backed regime had the support of the leader of the Fiji Indians. Chaudhry's position had, oddly, been strengthened by the coup. Internal fissures had surfaced within the Fiji Labour Party (FLP) during the eight months of Qarase's multiparty cabinet. Some Labour MPs assumed ministerial portfolios, but Chaudhry had remained on the backbenches. From there, he had sought to discipline a 'gang of five' FLP moderates who defied his authority by supporting the new power-sharing accord. Yet the coup had entailed a switching of roles, and now Chaudhry held a key position in the cabinet. In the new circumstances, former divisions could be healed by granting positions in the post-coup order to FLP sympathizers and trades unionists such as Felix Anthony, Daniel Urai and Agni Deo Singh. Nevertheless, cracks continued to appear. Outgoing FLP Nadi branch president Bijay Prasad publicly expressed his regret at endorsing the FLP decision to join the interim regime, saying that this marked the end of his party's aspirations to be a multi-ethnic party; 'With the suspension of the GCC, reduction of the ministry of Fijian affairs to a department of Fijian Affairs, and the overhauling of the NLTB [Native Land Trust Board] with concurrence of our members in the Cabinet, any hope of winning the indigenous support has evaporated in thin air'. ${ }^{18}$ In familiar fashion, Chaudhry responded that only corrupt politicians and chiefs were peddling the illusion of an alienated indigenous community. ${ }^{19}$ 
Chaudhry's leadership also faced challenges from other sources. Damaging revelations emerged about alleged tax evasion and fraudulent misappropriation of funds raised in India after the 2000 coup. $^{20}$ But, for the present, most Labour supporters did not believe the accusations and rallied behind their embattled leader. The overwhelming majority of the Fiji Indians either explicitly supported the coup or at least sympathized with the interim government. Yet Fiji Indians by 2007 accounted for only 38 per cent of the population, and therefore were unlikely to deliver sufficient votes to determine the political complexion of the next government. A more critical Indian perspective came from the minority National Federation Party (NFP), which, despite having secured no seats at elections in 1999 and 2006, retained a base both in the unions and in the municipal councils. NFP leaders kept up a high media profile, and harried the interim government and FLP leader Mahendra Chaudhry for all the injustices and constitutional breaches of the post-coup period. Would the extraordinary shift of the FLP into a post-coup government, after decades of criticism of those who acquiesced under earlier post-coup regimes, deliver greater Indian support for the one-time mainstream Indian-backed party? If so that would further compound the difficulties of the interim government.

Plausibly, a minority ethnic Fijian party willing to back the military's objectives might emerge. Yet something close to that had been tried before, at the May 2006 polls, when Ratu Epeli Ganilau's National Alliance Party of Fiji had secured only 2.5 per cent of ethnic Fijian votes and 2.9 per cent of the national vote. Ratu Epeli, the former RFMF commander, was politically close to Bainimarama, an affinity subsequently demonstrated by his joining the post-2006 coup interim cabinet. Perhaps the advantages of incumbency, popular acquiescence and post-coup 'realism' might boost support for such a party - if there were a breach of the commander's promise that interim ministers would not be allowed to contest the next election. After all, all manner of bribes, threats, age-old rural squabbles and sugar-coated enticements were being used to bolster political support for the regime's initiatives. Yet, by mid-2007, all the indications were that the post-coup assault on Fijian institutions had generated a seething discontent in the indigenous community. That disquiet was subdued only by fear of the military's monopoly over armed force.

Ultimately, the firmest indicator of the limited popularity of the interim government was its own evident timidity about facing the electorate. Ministers saw the writing on the wall. FLP leader Mahendra Chaudhry, the most experienced electoral campaigner in cabinet, was also the most vociferously and steadfastly resistant to holding a fresh election. Evidently, the interim ministers saw little realistic possibility that they, or their political allies, might secure a popular mandate at the polls. 


\section{The invention of obstacles}

A meeting of the PIF foreign affairs ministers in Vanuatu in March 2007 recommended the establishment of a joint PIF-Fiji government working group to monitor the implementation of the various steps required prior to the holding of fresh elections in Fiji. ${ }^{21}$ This, in turn, commissioned an 'Independent Technical Assessment of Election Timetable for Fiji', drawn up by a team led by New Zealand electoral specialist, Paul Harris. It concluded that an 'election could be held in February or March 2009 from a technical point of view', or by November 2008 if the Fiji Bureau of Statistics received assistance with drawing up a new census of population. The report urged that there be some correction to the current mal-distribution of constituencies following the census' and suggested several other changes. However, it recommended that broader changes, either to Fiji's alternative vote system or to the prevalent mix between 46 communal and 25 open constituencies were 'best reserved for consideration by the people of Fiji after the next election'. ${ }^{22}$

In response, cabinet agreed 'in principle' to hold an election in the first quarter of 2009, with the proviso that 'there should be a redistribution of constituency boundaries following the 2007 census, an update of the registers of voters, and voters' education and information programmes'. Based on that commitment, Bainimarama announced, 'it is now for the European Union and Governments of Australia and New Zealand to provide Fiji financial and technical assistance for the convening of national census, boundary redistribution, voter registration, voter education and information programmes, to the Electoral Commission and the Elections Office'. ${ }^{23}$ The new commitment was welcomed by Australian Foreign Minister Alexander Downer, and some aid was released for these electoral preparations. ${ }^{24}$ Parallel negotiations with the EU reached a similar conclusion, and Brussels announced its support for the PIF-Fiji working group roadmap. ${ }^{25}$

With the government now 'in principle' committed to hold elections in early 2009, attention shifted away in from electoral matters to other pressing concerns, and in particular to the mid-2007 challenge from the public sector unions (see Lutua and Naidu, this volume). Progress on implementing the agreed steps along the roadmap was slow. Doubts also existed about how genuine the electoral commitments were, fuelled - for example - by Bainimarama's statement in May that the RFMF did not conduct a coup 'just to have another election' and Chaudhry telling the media while in India that elections would be held in $2010 .{ }^{26}$ The New Zealand government accused Fiji's interim regime of 'playing for time' and seeking to play donors off against each other. ${ }^{27}$

Agreement by the interim government on the electoral timetable had been aimed at securing resumption of the flow of aid. Through renewed engagement, it was hoped, donors could be gently cajoled into further concessions, including cancelling the much-despised travel bans that prevented interim ministers and 
interim government appointees from entering Australia and New Zealand. The charade was fairly regularly exposed in domestic contexts. In July, Bainimarama told lawyers who petitioned the interim government to reinstate the ousted Chief Justice that if they continue doing this then the elections will be impossible in 2009 , it will be in 2020'. ${ }^{28}$ Australian and New Zealand travel bans, he claimed, were in fact preventing a return to constitutional democracy, pointing to the negligible number of applications for the vacant supervisor of elections post and claiming that this was due to antipodean travel blacklisting of regime appointees. $^{29}$ In August, he said that refusing to buckle to the demands of striking nurses was made easier by the fact that 'we do not have to worry about votes' $^{30}$ Like the lawyers, nurses were told their action could derail plans for a national election in 2009. ${ }^{31}$

A central part of Bainimarama's case for overthrowing the Qarase government became that the 2006 elections were rigged, although this had not featured centrally in the RFMF's public statements before the coup. ${ }^{32}$ In January 2007, soldiers released doctored tapes provided by convicted conman Peter Foster purporting to prove electoral fraud at the 2006 polls (see Fraenkel, chapter 3, this volume). But the evidence was quickly discredited, further releases of footage cancelled and Foster surreptitiously fled the country. ${ }^{33}$ The 'rigged elections' story did not die. In early May, interim finance minister Mahendra Chaudhry held a press conference, claiming that an audit by his ministry had discovered that 665,256 ballot papers had gone missing, and that this was definitive proof of direct attempts to 'interfere with and manipulate the results of the 2006 general elections' ${ }^{34}$ The allegations were strenuously denied by sacked supervisor of elections, Semesa Karavaki, who said Mr Chaudhry 'can't believe he lost in the election. The people of Fiji had spoken and now he is part of the illegal regime'. ${ }^{35}$ The timing of Chaudhry's statement was odd, particularly since there was nothing new about the allegations. Chaudhry had called for a hasty return to democracy soon after the coup ${ }^{36}$, but now he and his FLP colleague Lekh Ram Vayeshnoi had joined the interim cabinet. Were they under pressure to declare public sympathy for the coup? Speaking before a military passing-out parade in June, Vayeshnoi applauded the commander's coup, calling it a 'revolution for clean up' which 'had effectively removed all vestiges of racial discrimination in this country'. 37

\section{Were the 2006 polls rigged?}

The 2006 election had seen the arrival of Fiji's largest ever cohort of international election observers. A substantial and well-resourced team had arrived from the EU, and Australian and New Zealand monitors joined a team under the auspices of the PIF. The University of the South Pacific also assembled an official observation mission, as did the Commonwealth. All these teams found some evidence of administrative failings and some serious irregularities, but none 
concluded that the election had been rigged or that the obvious deficiencies had somehow determined the ultimate result. The outcome of the 2006 poll was largely in line with the expectations of the better-informed locally based and neutral political commentators: It was close and highly ethnically polarized, but the slight edge in the indigenous Fijian share in electorates tipped the balance in favour of Qarase's SDL. ${ }^{38}$

Chaudhry, whose largely Indian-backed FLP had in May 2006 obtained 31 seats in the 71-member parliament, afterwards claimed that irregularities in voter registration, vote-buying and 'poll-rigging' by Qarase's ruling SDL had deprived his party of victory. ${ }^{39}$ FLP claims of irregularities pre-dated the 2006 election; they were raised at the Electoral Commission's pre-poll dialogue sessions with political parties and in a stream of angry letters to the Supervisor of Elections. The allegations echoed the reaction after the 2001 election, when FLP leaders had difficulty suddenly adjusting to the shock of finding that they could not repeat their 1999 victory and so reverse the injustices of the 2000 coup. Defeated FLP candidates in the highly marginal open constituencies around Suva, like Lavinia Padarath in Nausori-Naitasiri, for many years after the 2001 election vociferously claimed that she had been robbed of victory, and she did so again after her defeat in 2006. None of these allegations were proven for 2001. After long drawn-out hearings, the courts rejected the petitions. ${ }^{40}$ Defeated candidates' and parties' statements are seldom credible sources of evidence for claims of electoral malpractice. Their incentives to exaggerate, accuse and deceive are self-evident. The FLP needed some way to explain to supporters why campaign trail promises of a return to the pre-2000-coup glory days had failed to materialize in 2001, and electoral skulduggery was the obvious choice. The protests after the 2006 election were far more muted, and far less convincing, than they had been in 2001.41

One reason for that contrast was that, in 2001, Qarase's government had used distribution of outboard motors, pitchforks, spades and other farming implements to solicit support in rural indigenous Fijian communities. One of Qarase's ministers had himself highlighted the importance of such largesse to the SDL's 2001 re-election chances. ${ }^{42}$ After the 2001 poll, key figures involved in the 'agricultural scam' were prosecuted. On the 2006 campaign trail, bags of rice or flour, and the perennial boosts to yaqona consumption filtered along the roads that led through Fijian villages. But vote-buying allegations could equally be levelled against Chaudhry's FLP, for which carefully targeted gifts had long been a favoured means of fostering political loyalties in the cane belts. The biggest expense for all the political parties was the supply of food and yaqona at the vibrant party sheds set up close to polling stations and outside the counting centres at election time. While the vote-buying allegations thus had some substance, the vote-rigging allegations were extravagant, unproven and 
inflammatory. Irregularities there were, but these were mainly because seconded civil servants struggled with registering Fiji's eligible citizens, arranging the printing of the required number of ballot papers, organizing timetables for polling station opening times, shifting the ballot boxes to the counting centres, and tallying the preference votes marked on Fiji's over-elaborate ballot papers.

In the wake of the coup, the FHRC initiated a commission of inquiry into the 2006 polls; it was undertaken by Suva lawyer G.P. Lala, former MP Taufa Vakatale and a radical political economist from Waikato University, Dr David Neilson. ${ }^{43}$ The title of the resulting report was 'From Roadhumps to Roadmaps', presumably to convey disdain for the obstacles cast in Fiji's way by international donors and to outline a more appropriate path back to democracy. It claimed (i) 'significant failures to ensure citizens' right to vote', (ii) 'significant biases in these failures primarily against Indian voters to the unfair advantage of the SDL', (iii) 'inappropriate "vote-influencing", vote-buying and vote-rigging to the unfair advantage of the SDL', (iv) 'the concentration of bias, vote-influencing, vote-buying and vote-rigging in the key urban open constituencies which is where elections in Fiji are won and lost'. The report was sloppy in construction, and full of spelling and factual errors, a sign of what one otherwise sympathetic reviewer generously called 'undue haste in its preparation'. ${ }^{44}$ No reference was made to the difficulty of conducting a retrospective review of an election the result of which had been cancelled out by a coup. Nor did it mention any problem arising from the fact that the report had been commissioned by FHRC director Shaista Shameem, who had previously associated herself firmly with the military takeover. But it did mention the RFMF, describing its role as that of a "last resort defender of democracy' which had needed 'to suspend "democracy" in order to protect democracy'. ${ }^{45}$

The method chosen by the commission was just as flawed as its inspiration. It reached the verdict that the 2006 result had been 'rigged' largely on the basis of evidence gleaned at public hearings, without any independent effort to verify the accuracy of the evidence. When critics said the commission had failed to analyse the statistical plausibility of its extravagant claims, the team replied that this was 'beyond the resource and time constraints under which the report was prepared' ${ }^{46}$ This was a staggering claim. Public enquiry under conditions of military rule was scarcely an adequate way of testing whether an election 16 months earlier had been free and fair. The vast majority of the 59 submissions drawn upon came from those who had lost the election or, for one reason or another, had an obvious axe to grind. Only one submission came from the former governing party, the SDL. Whatever substance was in the report echoed the far more thorough and careful conclusions, based on more extensive, more independent and more reliable methods of evidence-gathering, by the various May 2006 electoral observation teams. But the FHRC commission ventured to 
claim systematic ethnic bias and ballot-rigging solely on the basis of hearsay and anecdotal evidence, condemning the other reports as based on 'first-worldist' perspectives. ${ }^{47}$

The core allegation that there had been 'ballot rigging' by the SDL, and that this was particularly apparent in the key highly marginal urban open constituencies, had no solid foundation. The bases for this claim were (i) the 'pattern of complaints' (p.9), (ii) Dr Neilson's observation of systematic bias in the issuing of registration slips and (iii) the argument that that those administrative deficiencies identified in all the observer reports ultimately indicated such irresponsibility as to legitimately be called an 'anti-democratic act' and to generate 'suspicion of corrupt practice' (p.35). The story about bias in the issue of registration slips is the only one of these allegations that merits serious attention.

Registration of voters was the weakest element of the 2005-06 Election Office preparations, as all the observer reports indicated. Eligible citizens were left off the rolls or registered in the wrong constituencies, a familiar problem in elections across the Pacific. At the time of registration, citizens were given coloured slips of paper indicating in which two constituencies they were eligible to vote, and these were colour-coded by ethnic group (pink for the Fiji Indians). The FHRC report explained the rather impressionistic sequence of its findings of deliberate bias and ballot-rigging:

It was only when the Commission reached Savusavu that the New Zealand Commissioner, in a conversation with one of the District Officers, realized that the pink slips were only for Indo-Fijians! Registration problems were overwhelmingly confined to this one group. Only once the Inquiry was reaching the end of the submissions, and had returned to the greater Suva area, did it become apparent that one particular registration problem was recurring in a way that seemed more than accidental. Indo-Fijian voters were being registered in the correct communal constituency, but incorrectly in the open constituency. Further submissions indicated that this particular problem tended to occur in the main urban centres, especially around the Greater Suva area. This pattern is suspicious because of one significant fact, as was pointed out by Rev David Arms (submission 52); in Fiji elections hang in the balance around a relatively few number of open constituency seats in the major urban areas. Thus, vote-rigging, if it is going to be pursued, would be likely to be concentrated in these marginal seats (p.13).

This was evidence by insinuation. To jump from alleged concentration of registration errors in the Suva-Nausori area to 'suspicions' of ballot-rigging because, if elections were rigged, this is geographically where it would be done, is disjointed reasoning. There are plenty of plausible reasons why registration errors might be largely found in the densely populated Suva-Nausori area, which 
is covered by many interlocked open and communal constituencies, as compared with the more sparsely populated countryside.

More importantly, the basic premise about the link between the issue of registration slips and the electoral rolls was flawed. Errors on the registration slips handed out to voters were reasonably common, but affected somewhat less than 1 per cent of all voters, and not just Indo-Fijians, but everyone. ${ }^{48}$ This did not mean, as the commission apparently believed, that voters were actually registered in the wrong place on the rolls. ${ }^{49}$ It only meant that the forms issued to them to tell them where to find their names were incorrect. Polling officials could easily correct this, and often did so if they understood the system, since at the end of the rows, next to each voter's name on a communal roll, was the number of the corresponding open constituency, and vice versa. Members of the FHRC Commission of Inquiry, like many of the polling station officials, were apparently unaware of this important detail about the methodology used in the Fiji voter registration system. Nonetheless, this was the core reason for claiming evidence of ballot-rigging.

The claim that administrative failings indicated 'corrupt practice' or that fraud could be confirmed by submissions from unsuccessful politicians or parties (or those like the government printer with an obvious grudge against the Supervisor of Elections) were even less credible. In other words, despite now having full control over the administrative arms and records of the state, the interim government's supporters were evidently struggling to find solid evidence that the 2006 election had been rigged. In fact, they were not even looking in the plausible direction. ${ }^{50}$ The allegations by interim ministers about electoral fraud were thus largely self-serving bombast and showmanship.

\section{The power of chiefs, padres and pastors}

'The 2006 general election was not credible', Commodore Bainimarama told the United Nations General Assembly in New York in September, 'it was characterised by massive rigging of votes with the incumbent government using the state's resources to buy votes' ${ }^{51}$ In addition to these more recent difficulties, the commander told the UN General Assembly that his military takeover had been a legitimate reaction to decades of defective democracy:

The "democracy" that came to be practiced in Fiji was marred by divisive, adversarial, inward looking, race-based politics. The legacy of leadership, both at community and national levels, was a fractured nation. Fiji's people were not allowed to share a common national identity. Of the two major communities, indigenous Fijians were instilled with fear of dominance and dispossession by Indo-Fijians and they desired protection of their status as the indigenous people. Indo-Fijians on the other hand, 
felt alienated and marginalised as second class citizens in their own country, the country of their birth, Fiji. ${ }^{52}$

That post-independence democracy had become race-based, adversarial and divisive was not in doubt, although the claims that Fiji's citizens were 'not allowed' to share a common national identity were unfair to the efforts of Ratu Mara in the 1970s, and exaggerated the impact of his successors in generating race-based politics. Promoting positive images of multi-ethnic harmony was a regular feature under all governments, including that of Mahendra Chaudhry during 1999-2000. Television adverts shortly before the coup had encouraged popular support for Qarase's power-sharing experiment through messages from local celebrities and politicians, including Imrana Jalal, Ratu Joni Madraiwiwi and Krishna Datt.

The comments about the failures of leadership, included by Bainimarama's speech-writers, were more controversial, since these were primarily aimed at indigenous Fijians. Such claims were increasingly used to chastise those pressuring Fiji to hold early elections. 'The countries that are urging us to return to democracy', said Bainimarama in an unscripted remark, 'I don't know if they understand how unfair the system has been over the last 20 or 30 years':

Fijians live in a democracy with a mentality that belongs to the Fijian chiefly system. They decide for us who to vote for, our church talatalas [church ministers] decide for us who to vote for. These are the Fijians living in the villages and rural areas. The provincial [chiefly] councils dictate for us who to vote for and we go along with that. ${ }^{53}$

Indigenous politics has proved more complex, multi-faceted and changing than this suggests. In rural areas, the provincial councils have indeed often been able to influence the selection of indigenous candidates, just as the National Farmers' Union can pull the Indian vote behind the FLP candidate in the cane belts of western Viti Levu and northern Vanua Levu. But Fijian chiefs have often been defeated at the polls. ${ }^{54}$ 'Commoners', like Rabuka and then Qarase, emerged as the core Fijian leaders of the 1990s and the new millennium, whereas high chiefs, like Ratu Mara, Ratu Epeli Ganilau and Ratu Epeli Nailatikau, found themselves out of favour. Those eastern chiefs, paradoxically, were to become the key Fijian backers of Bainimarama. Ratu Epeli Ganilau's National Alliance Party, which in TV adverts emphasized its ancestral linkages with the grand chiefs of post-war Fiji $^{55}$, went to a crashing defeat at the 2006 election. Both Ganilau and Nailatikau joined Bainimarama's interim cabinet after the 2006 coup. Bainimarama's attack on chiefly influence was thus highly partisan, and did not preclude his drawing on the support of disgruntled chiefs where this suited his purposes.

The influence of the Methodist Church on indigenous voters has also been strong, particularly in the urban areas (see Newland, this volume). At the 1999 election, 
the Methodist-backed Veitokani ni Vakarisito in Lewenivanua (VLV; Christian Democratic Party) proved decisive in ensuring the defeat of Rabuka's Soqosoqo ni Vakavulewa ni Taukei (SVT). ${ }^{56}$ The VLV was associated with the Mara dynasty, and Mara had appointed Bainimarama as military commander in 1999. The VLV's 1999 leader, Poseci Bune, joined Bainimarama's cabinet after the 2006 coup. Adi Koila Mara (Ratu Mara's daughter and also a 2006 coup-sympathizer ${ }^{57}$ ) became another of the VLV's three MPs in 1999. Also in 1999, Ratu Epeli Ganilau stood unsuccessfully for the VLV in Cakaudrove West. In 2001, public Methodist endorsement for two new parties - Qarase's SDL and the Conservative Alliance-Matanitu Vanua - was an important reason for their achieving respectively 50 per cent and 20 per cent of the indigenous Fijian vote. By contrast, Hindu and Muslim religious organisations are generally less important in determining Indian voting patterns. Like minority community politics in many other parts of the world, Fiji Indian politics has been more overtly secular - in part to resist Methodist demands for Fiji to be turned into a 'Christian state'. 58

Catholicism, the religion of Bainimarama's wife, also became an important prop for the post-2006 coup interim regime, much to the horror of prominent Catholics associated with the deposed government (like Ro Teimumu Kepa, paramount chief of Rewa province and former education minister). Catholic Archbishop Petero Mataca indicated strong sympathies with the commander's transformative project, and other members of the Catholic clergy, such as Fathers Kevin Barr and David Arms, became involved in the regime's initiatives. Complaints about the Catholic Archbishop's involvement with the post-coup government were sent by indigenous Catholics to Rome, but went unanswered. In June 2008, the Pope met Commodore Bainimarama at the Vatican, and the news reverberated back to Fiji. What was not reported was that Bainimarama bought a ticket for one of the regular papal public audiences, stood in line, and when his turn came basked in the resulting photo opportunity.

In Bainimarama's United Nations speech (as cited above), indigenous Fijians were described as having been 'instilled' with race-based hostility towards Fiji Indians, while Indo-Fijians 'felt' alienated and marginalized. In other words, Indians held legitimate moral grievances, whereas the ethnic Fijians had been duped by their leaders. Yet many Fijians also felt alienated and marginalized, indicating frustration at the prosperity of the Indian middle classes in urban areas or at Indian dominance of the commercial sector. Unlike ethnic Fijian politics, Indian politics is seldom publicly and explicitly couched in terms of communal interests. Nevertheless, on the campaign trail and in the vernacular, subtle ethnic messages are regularly conveyed about the forces of 'darkness' and 'light', about poor indigenous economic performance ('incompetence' and 'sleeping on the job' are regularly heard expressions) and about the alleged dismal failures of post-independence Fijian political leadership. Fiji Indian support for the coup entailed a rejection of the power-sharing cabinet attempted during 
the May-December 2006 Qarase government, symbolized most vividly by the burning of an effigy of FLP cabinet minister Krishna Datt at an FLP meeting in Nasinu (Suva) shortly before the coup. Was this not also an example of Fiji's citizens being 'instilled' with communalist ideology by leaders playing ethnic politics?

If chiefs and talatalas (pastors) exert such strong influence over indigenous electoral loyalties, should urban reformers seek to annihilate this? Villagers look to political representation by chiefs, pastors or provincial councillors to provide an otherwise-lacking conduit for accessing state resources (eg. for building a road, or school or clinic) or for legal protection of customary rights. Where such links are absent or attenuated, for example further west in Melanesia, the state is correspondingly weaker. When chiefs or churchmen articulate communal aspirations, this is sometimes accompanied by inflammatory racial rhetoric. But, in the broader view, ethnic frictions between Fijian and Indian are underpinned by real issues - for example, land leasing arrangements, the desirability of affirmative action programs to combat disadvantage or political control over the state - which are poorly handled politically by dismissing these as based on 'racist' positions or claiming that these are efforts to sustain an 'apartheid' social order. Representing Fijian ethno-nationalism as a dogma 'instilled' by unscrupulous leaders only weakens the political will to negotiate indigenous hopes and fears. An advantage of electoral democracy is that it draws representatives of these various forces into political contexts where these issues must be transparently dealt with, even if doing so simultaneously generates a dangerous potential for top-level confrontation and obstruction. The utopian goal of seeking to transcend those social forces by destroying them is tantamount to aspiring to leave indigenous Fijians rudderless, inarticulate and estranged.

\section{The advantages of sheep's clothing}

At a meeting of the PIF in Tonga in mid-October 2007, Bainimarama made a firm and much-publicized commitment that an election would be held by March 2009, without the qualification appended to earlier statements. The promise was welcomed by Australia, New Zealand and the United States, as well as by Qarase. The Fiji interim prime minister again called on donors to now drop sanctions and step up the flow of aid. New Zealand Prime Minister Helen Clark responded that she would 'keep Fiji's feet to the fire', explaining 'we need to see benchmarks met'. 59 'Everything that needs to be done to prepare ourselves for the election has been done completely', responded Bainimarama, pointing out that the 2007 census of population had been completed and that preparations were well underway towards establishing a Constituency Boundaries Commission. 'What else do they want?', he asked, 'people come up and tell me you have to show us concrete steps - what further steps?' ${ }^{60}$ 'They think I have evil intentions', said Bainimarama jocularly, 'and that I want to stay around for the next 10 years' ${ }^{61}$ 
Perhaps those assurances were genuine, some believed. Perhaps after the brief military interlude, Fiji would revert quickly to elections, as had occurred after the 2000 coup.

Actions within Fiji suggested that the commander's commitment was not made in good faith. Contrary to agreements with the EU, public emergency regulations had been reintroduced in September 2007 following Qarase's return to Suva 'to restrain ousted Fiji Prime Minister Laisenia Qarase and his party executives from destabilizing our progress' ${ }^{62}$ Political parties - such as the NFP and SDL - were prohibited from meeting, and indicated their outrage that political bans did not extent to the FLP. ${ }^{63}$ SDL National Director Peceli Kinivuwai, was taken up to the Queen Elizabeth Barracks for interrogation at least 16 times during 2007. 'We will not let any government push us forward to have elections', military spokesman Lieutenant Colonel Mosese Tikoitoga told the Fiji press, 'we want to have all the conditions in place before we proceed with an election' ${ }^{64}$ In early October, an EU council meeting in Luxembourg had resolved to cancel US\$30 million worth of commitments for Fiji for 2007, and that 2008 and 2009 commitments would be subject to further discussions under article 96 of the Cotonou Agreement and Article 37 of the Development Cooperation Agreement. ${ }^{65}$ Bainimarama responded 'right now it's better that we do not provoke them in any way otherwise they will not give us any funding' ${ }^{6}{ }^{6}$

Preparations in Fiji were, by the time of the commander's October Forum statement, already well under way for a National Council for Building a Better Fiji (NCBBF), which was to deliberate - among other issues - on plans to thoroughly overhaul Fiji's electoral system. The NCBBF was designed to draw on support from various sections of civil society for the interim regime's goals of fighting corruption, combating poverty and challenging racism. Bainimarama was to be co-chair, together with Fiji's Catholic Archbishop, and the goal was to produce a 'People's Charter' by October 2008. The commander had sought to gain PIF endorsement of the NCBBF process, but this had been merely 'noted' in the Tonga final communiqué. ${ }^{67}$ Outside the Forum retreat venue at the picturesque waterfront Vava'u resort, the commander hedged his election commitment with qualifications: 'We might change the constitution before the election', he told the assembled journalists. 68 'The charter will make sure there is no racial discrimination again ever', he explained 'so if anybody with Qarase like policies comes in, the charter will automatically remove them' ${ }^{69}$ The Attorney-General, Aiyaz Sayed-Khaiyum, who was accompanying Bainimarama, also equivocated about the election date, and downplayed the significance of the commitment to the Forum. ${ }^{70}$

Within Fiji, hostility to the overseas-brokered election timetable had become a popular rallying cry amongst those sympathetic to the interim government's program. The Catholic Archbishop and Ecumenical Centre for Education, Research 
and Advocacy (ECREA) activists expressed such sentiments, as did civil society organizations like the Citizens' Constitutional Forum (CCF), and so most vociferously did the FLP. Australia and New Zealand were regularly condemned for insisting on an excessively hasty return to elections, rather than allowing time for reforms aimed at facilitating the emergence of 'deep rooted democracy' ${ }^{71}$ Jokapeci Koroi, the FLP president, accused Australia and New Zealand of bullying Fiji. 'They have exploited us commercially, treating us as a little colonial empire in their backwaters', she said, claiming that the PIF was little more than an instrument of neo-colonial oppression. The FLP had been the victim of vote-buying, vote-rigging and political interference with the electoral process, said Koroi, 'unless the system is overhauled to address these problems, holding another election will be farcical'. ${ }^{72}$ This was a transparently self-serving comment, since changes to electoral laws in themselves do little to prevent ballot-rigging or vote-buying. But the FLP was by now firmly ensconced in the military-backed interim government and wanted to remain in that position for as long as possible.

At its inaugural NCBBF meeting in Lami in January 2008, co-chair Archbishop Petero Mataca explained to participants: 'There are those who want elections to be held imminently, so that we can return to democracy as soon as possible, but elections alone will not bring about democracy nor guarantee stability or end all coups' ${ }^{73}$ Early training sessions leading up to the inaugural NCBBF meeting had been held at the Queen Elizabeth Barracks, but civil society participants like the CCF's Akuila Yabaki - urged the military to adopt an arms-length stance towards the NCBBF process. ${ }^{74}$ Both of the major North Indian Hindu organizations joined the Council, although the Fiji Muslim League and the small but vocal NFP stayed out. So, critically, did the SDL and the Methodist Church, signalling that ethnic Fijian enthusiasm for the council was minimal. Those moderates that did join insisted that the role of the military itself be considered, since this was integral to the objective of ending Fiji's 'coup culture'. Deliberations were to be inclusive, insisted director of the NCBBF technical secretariat John Samy, a former Asian Development Bank consultant, and seats at the table would be left vacant for the SDL and Methodist Church, should they relent on their refusal to participate. ${ }^{75}$

Although participation was open to adversaries, the agenda was clearly non-negotiable. Why would the SDL want to participate in a forum intent on stopping people with 'Qarase-like politics' from assuming office? Was the intention to ban ethnic political parties, as has been undertaken - usually unsuccessfully - in so many other parts of the world? Plausibly, Bainimarama's threat to ban the SDL did not reflect the position of the technical secretariat or the rest of the NCBBF membership. However, Archbishop Mataca, too, said that the charter should serve as a binding 'covenant' for the future, a phrase 
subsequently much echoed by the commander. ${ }^{76}$ John Samy said 'it is anticipated that the political parties that will contest the March 2009 general election will all have manifestos in which the contents of the People's Charter contents will dominate' ${ }^{77}$ Some accolades were still more effusive; University of Fiji academic Professor Satendra Nandan called the as yet unwritten charter 'the most sacred text after the bible in the history of Fiji' ${ }^{78}$

Other NCBBF participants' views of the charter process differed. Some, including moderates like Media Council director Daryl Tarte, former opposition leader Mick Beddoes and civil society activist Suliana Siwatibau resigned in early 2008, citing lack of independence of the NCBBF from the interim government and the military. Samy told Fiji TV's Close Up program in January 2008 that he opposed the coup, but he did not explain why he saw an initiative launched by the consequent military-established interim regime as a vehicle for social transformation. He had been called upon to set up the NCBBF by Mahendra Chaudhry, but the FLP too had reason for concern that the military's ever-changing agenda might shift yet again, and that the 'charter process' might be steered in unwanted and uncontrollable directions. Former Chief of Police Josefa Savua predicted that the People's Charter would ultimately reflect the military's aspirations, not those of the civil society activists who had pinned their utopian hopes and aspirations on these deliberations. ${ }^{79}$

'Why do you think we're here running the country instead of the politicians who should be here instead of us?' asked Bainimarama in September 2007, 'we keep removing them. Why? I don't think the politicians are ready to take this country forward. That's why we think our exit strategy is the Charter. That will form the basis of good governance. That way we can move away from all this' ${ }^{80}$ This was a justification of all Fiji's coups, including those in 1987 and 2000 that had removed Chaudhry and his FLP from office. It was not the voice reflected by the public speech-writers, but that of a military coup-maker indicating disdain for the shabby compromises and posturing of elected politicians. Nor was it an isolated statement. In October, Bainimarama repeated again to the Fiji press that 'you cannot afford to have a civilian as a Prime Minister' ${ }^{81}$ Clashes between cabinet ministers rarely reached the Fiji media, but a reshuffle in January removed Poseci Bune, who was known to have fought with Chaudhry. Chaudhry himself was investigated by the RFMF after allegations of financial impropriety, although the end result was a whitewash. For the present, Bainimarama needed his finance minister to give robustness, coherence and legitimacy in the Indian community to an otherwise unpopular government. But in Fiji's ever-shifting political landscape, it was never quite clear where contemporary allies might stand a few months hence.

Meanwhile, progress on the Forum-monitored roadmap was beset by public relations disasters. Adi Koila Mara was appointed to head the required 
Constituency Boundaries Commission. But she had been a Senator in the previous government, so her appointment was unlawful and it was cancelled, much to the embarrassment of the Attorney-General. ${ }^{82}$ Newly appointed High Court Judge Jocelyn Scutt publicly criticized the 2006 international election observers in February and applauded the FHRC report on the 2006 election, much to the horror of the Fiji Law Society. ${ }^{83}$ The government selected a Supervisor of Elections, only to find that he had been disbarred in New Zealand in 1992, and he too had to be replaced. ${ }^{84}$ New technical obstacles were arising every week. The school timetable made a March 2009 election impossible, said Bainimarama in May. ${ }^{85}$ Others pointed out that the hurricane season only finished in April, two months after the scheduled election date. For some overseas mediators, their own ambivalent and pragmatic attitudes towards Fiji's coup were manifested through acquiescence to the electoral delay. After negotiations with the commander in June, PNG Prime Minister Sir Michael Somare acknowledged uncertainties about the timetable, explaining that 'there are logistical issues that the Fiji interim government is in the process of resolving' ${ }^{86}$

The political motives behind the interim government's desire to delay the election were always fairly obvious, but they became more explicit during early 2008. 'Now we want to have an election', the commander told journalists in May, 'but we want to have an election on my terms so that we can cut out the coup mentality' ${ }^{87}$ The 'coup to end all coups' theme of the interim prime minister's October 2007 UN Speech was now recycled into a reason for not holding elections. 'We have to break the vicious cycle of elections followed by coups; that is what has been described as the "coup culture" in Fiji', the commander said. ${ }^{88}$ Hasty elections, he explained, would be 'impossible under the current electoral system as the system itself is undemocratic ... it violates the UN Universal Declaration of Human Rights'. ${ }^{89}$ Attorney-General Aiyez Sayed-Khaiyum admitted that earlier commitments had only been meant to hoodwink the EU into releasing sugar subsidies. ${ }^{90}$ By May, it was glaringly obvious that the interim government intended to renege on its March 2009 election commitment. Elections would now, the commander said, be held 'as soon as possible in $2009^{\prime}{ }^{91}$ In Nadoi (Rewa) in May, Bainimarama told villagers that unless they endorsed the People's Charter there would be no election. ${ }^{92}$ A Commonwealth Ministerial Action Group meeting in London expressed grave concern at apparent slips in election preparations. 93

\section{Roadmap to Damascus}

The new rationale for electoral delay, drawing succour from the NCBBF's deliberations, was now an urgent need for wholesale electoral reform. As Chaudhry put it in May, it was necessary to 'put our fundamentals right before an election is held' .94 Until we fix the electoral system' he claimed, 'you cannot get rid of racism in the country'. ${ }^{95}$ John Samy said that the 1997 constitution 
had served to 'entrench, perpetuate and legitimise race-based, divisive politics. It has been the antithesis of national unity. It has undermined democracy' ${ }^{96}$ The 'current race-based electoral system has failed to deliver social cohesion and inter-ethnic cooperation', Bainimarama told one of the NCBBF meetings. 97 'The common roll is the way to go', he claimed, because 'it takes away the race card' ${ }^{98}$ Similar arguments were echoed by NGO activists, such as the CCF's Reverend Akuila Yabaki and ECREA director Chantelle Khan. ${ }^{99}$ When the NCBBF's 'National Task Team on Good Governance' report was released in June 2008 it called for 'the complete abolishment [sic] of the communal representation system' and for 'common roll for all future elections'. 100

The case for a common roll had long been urged in Fiji. ${ }^{101}$ It had been pressed by Indian politicians back in the 1920s, when the colonists first introduced communal voting, and when use of communal seats for Indians had been viewed as an instrument of colonial oppression. The claim that communal voting was responsible for race-based voting was expressed by A.D. Patel and the Indian delegation to the 1965 London talks. It was echoed by the 1975 Street Commission and in a more sophisticated way by the 1995-96 Reeves Commission. ${ }^{102}$ That this style of electoral organization, in one sense, nudged outcomes in a communalist direction was not in doubt. ${ }^{103}$ Yet attributing Fiji's post-independence ethnic polarization to institutional design was a gross exaggeration. Even in the common roll contests during $1972-87^{104}$ and 1999-2006, there had been very little inter-ethnic voting. Plausibly, political parties primarily constituted for communal contests had tended to fight the common roll contests in a similar fashion. After all, even many of Fiji's common roll constituencies were so ethnically unbalanced that they were sometimes called 'communal seats in disguise'. ${ }^{105}$ But, if this view were correct, Fiji would have some history of multi-ethnic political parties performing reasonably well in the highly heterogeneous common roll seats in the Suva-Nausori corridor, but struggling to make headway in the communal contests. ${ }^{106}$ In fact, ethnic political divisions since independence were stronger in the inter-mixed areas around the capital, Suva, than in the so-called 'friendly north' (Vanua Levu) or western Viti Levu. In its mid-1970s heyday, for example, the extremist Fijian Nationalist Party secured its highest vote share in the urban and peri-urban areas of eastern Viti Levu, and was never strongly supported in the cane belts or on the outer islands.

Fiji is unique in classifying all its citizens by race for electoral purposes. ${ }^{107}$ Other countries, however, have strongly ethnic, religious or communal voting patterns. Northern Ireland, for example, has a Catholic/Protestant or Republican/Loyalist division that strongly influences voting patterns. ${ }^{108}$ Yet it does not have communal constituencies. Nor does Guyana, where Indo-Guyanese and Afro-Guyanese have long backed distinct, communally based, political 
parties. $^{109}$ Ethnic voting is reasonably common internationally, but separate communal constituencies are a rarity.

The interim regime also appropriated other aspects of the $\mathrm{NCBBF}^{\prime}$ s transformative agenda. In a paper for the NCBBF's National Task Team 1 on Good Governance, David Arms recommended the abolition of Fiji's alternative vote system and instead suggested the adoption of an open list proportional representation system. ${ }^{110}$ Plans were also announced to lower the voting age from 21 to 18 ; to abolish compulsory voting; to end use of power-sharing provisions; and to restrict cabinet size. 'As the military regime [is] more or less acting outside the Constitution', Father Arms proposed, 'the NCBBF should take the opportunity to push through the electoral reforms and amend the Constitution, by taking advantage of the military authority and ignoring the legal constitutional requirements for making such changes'. The suggestion was condemned as 'treasonous' by former Leader of the Opposition Mick Beddoes, who lamented that 'men of God' were in cahoots with 'a military Junta, whose actions to date have been against the will of the people'. ${ }^{11}$

While many of the National Task Team 1 proposals were sensible, seeking to introduce these on the back of a military coup was not. As deposed Vice-President Ratu Joni Madraiwiwi, himself a long-standing supporter of proportional representation, told the Fiji Institute of Accountants in June, 'the tragedy is that many beneficial features in the proposed charter and the electoral system would be discounted and discredited because of the manner of their implementation'. The People's Charter and the new electoral system would not be sustainable if forced on the people. ${ }^{112}$ Ironically, Qarase himself had contemplated abolishing communal rolls prior to the coup, recognizing that this might hold advantages for the numerically preponderant Fijians. ${ }^{113}$ Neither the introduction of a common roll system nor the abolition of the alternative vote system were likely to threaten indigenous Fijian preponderance in government, if they backed a single party. But now, in the bitterly divided circumstances of post-coup Fiji, Fijians were likely to take any available opportunity to contest any of the interim regime's initiatives, whatever their intrinsic value. Rewa Chief Ro Filipe Tuisawau, for example, condemned the common roll proposal, saying it had been urged by 'non-Fijian leaders since 1970' but that 'Fijian Chiefs and leaders have consistently opposed this call in order to protect their heritage and interests' 114

Using military ascendancy to force through electoral reforms ran the risk of further politicizing voting institutions, and consequently damaging the legitimacy of any post-election government. One alternative was a referendum on the proposed electoral reforms. Despite there being no legal provision for constitutional amendment through referendum, the courts would be unlikely to overturn a popularly backed outcome. But, again, the likelihood was that 
such a referendum might elicit support only from the regime's sympathizers, and be rejected by the majority of indigenous Fijians.

An alternative was to accomplish reform by achieving a consensus with Qarase and the SDL, as well as the other smaller parties. Parliament might be temporarily reconvened only to agree the changes, and then dissolved ahead of an election. Qarase had offered such a course of action. ${ }^{115}$ The commander refused, fearful of acknowledging the political importance of his arch-adversary, saying 'we dictate how things go. Nobody tells us what to do'. ${ }^{116}$ What to do about the charter proposals thus became linked to the controversy about the electoral timetable. Could Fiji be governed without the consent of the majority? Could electoral changes or the People's Charter be adopted without broad legitimacy? By mid-2008, the motley collection of civil society activists, modernist military officers, Catholic social justice advocates, Hindu religious leaders and FLP supporters who had pinned their hopes on a 'good governance' coup had come to a predictable impasse. Essentially the same question of legitimacy would beset them on every route out of crisis, whether towards the promised electoral deadline or towards the rubber-stamping of their reformist institutional proposals.

\section{End of the roadmap}

Reneging on the agreed election timetable generated dangers of isolation. Alternatives were sought. Sir Paul Reeves, the chair of Fiji's mid-1990's Constitutional Review Commission, visited the country to broker talks in December 2007, ${ }^{117}$ and returned in the New Year as Commonwealth Envoy. After appeals from the Office of the President, he returned yet again in July 2008 to set up a political forum. Ahead of Sir Paul's arrival, as a gesture of commitment to talks, Bainaimarama met with Qarase over draunimoli (lemon tea), for negotiations brokered by Catholic and Methodist church leaders. ${ }^{118}$ Aware that alternative methods of international engagement were in the offing, including also a visiting EU Troika mission, the commander wrote to the PIF 'I have decided that Fiji will no longer participate in the Forum Working Group meetings until such time [as] the positions of Australia and New Zealand are genuine'. 119 The Attorney-General said that the EU Troika Mission was 'more flexible', 'more facilitative' and 'more engaging partners' than the Joint Forum Working Group. ${ }^{120}$ Only month later, he condemned the EU mission for inappropriately focusing on the election timetable. ${ }^{121}$

In mid-July 2008, the commander finally, publicly and unequivocally, declared that 'there will be no elections next year'. ${ }^{122}$ Cabinet had always planned to hold elections only in 2010, he said. The earlier qualification - that the March 2009 deadline was only an 'in principle' commitment - had only been removed as a result of entreaties from Pacific Island Forum chairman Feleti Sevele. 
What I gathered was that he said whilst you kept the 'in principle' in front of the March 2009 - it tells the international community you will never have elections so take away the 'in principle', keep the March 2009 - announce to them the March 2009 and if there's any extra time for elections that you want, we will be quite flexible coming out with additional timing so I took that on board and that's how I came up with March 2009 at the Forum on the understanding if there's need to be an extension in time the International Community will be very flexible. [sic]

Dr Feleti broadly confirmed the commander's garbled account of the behind the scenes diplomacy at the Forum's October 2008 meeting, saying:

... the Forum Leaders did not want such a diluting qualification in the communiqué. We also added that if having taken all reasonable steps towards holding the elections as promised, the Fiji interim Government found that it was genuinely and practically impossible for Fiji to hold free and fair elections in the first quarter of 2009, then the Forum Leaders would, as reasonable people, be flexible about extension of the agreed deadline. $^{123}$

The charade in this was twofold. First, it was that foreign powers were somehow in control of the process, and that they could give 'deadlines' and 'extensions', as if to students whose essays are overdue. Second, it was that delays were due to technical obstacles, as if the reluctance of a coup-leader to relinquish power to an elected government was not political at all. The diplomatic advantages of that myth were that it kept overseas sympathizers and opponents of the Fiji coup united around the pressure for a fresh election, but it also made that pressure susceptible to myopic technical objections and ensured that dialogue became entangled in a focus on process rather than substance. The principal usefulness of the March 2009 deadline was symbolic, and its justification was as an echo of what domestic forces - although restrained by military oppression - were themselves urging. It entailed pressure for an acknowledgement by the interim regime that its tenure was only temporary, and that Fiji's longer-term future lay in a restoration of constitutional democracy.

\section{Conclusion: The primacy of domestic discontent}

For the first year and a half following the coup, the regime had sought to cultivate popular support for its various initiatives, such as the review of the Great Council of Chiefs (GCC), and the NCBBF. In the end, a Presidential decree made changes to the GCC that were so unpalatable to Fijians that even members of the review team resigned. The island of Kadavu dropped Josefa Nawalowalo as provincial chairman after he associated himself with the regime's decree to reconfigure the GCC. Support for the NCBBF amongst indigenous Fijians was, at best, patchy. 
In Rotuma, Macuata and Serua, provincial chiefs indicated a willingness to embrace the new reform agenda. Qarase supporters were locked out of a meeting of the Lau provincial council meeting in June 2008 in a mini-coup that saw Ratu Mara's son and military officer, Ratu Tevita Uluilakeba, assume the chairmanship. Lau's faded glory since the death of Ratu Mara in 2004, it was hoped, would be resurrected through the new military-dominated political order. Most of the core Fijian provincial councils -including Naitasiri, Tailevu, Cakaudrove, Rewa, and Namosi - remained steadfastly opposed to the interim regime's initiatives. Critically, no high profile splits amongst the SDL leadership had occurred that might give the commander a much-needed political niche. One ambitious SDL minister, Jonetani Navakamocea, had joined the January 2007 interim cabinet, but he was dropped in a January 2008 reshuffle and subsequently protested that an inner circle kitchen cabinet was running the affairs of state. ${ }^{124}$

By mid-2008, Bainimarama had destroyed the careers of the bulk of the ethnic Fijian elite, by purges ranging from the public sector to the boards of state-owned companies and even to listed companies like Fijian Holdings Ltd. Had Fijian society been primarily class-based, this might have translated into grass roots support for the military regime. But it was not. Most Fijian families were hit hard by the removal of breadwinners from positions of influence. Some also benefited, and many had amongst their relatives both beneficiaries and those who had been deposed. The severity of the economic downturn ensured that what gains there were did not offset the losses.

Amongst the civil society activists, there were enthusiasts and visionaries who felt they were in the throes of a social and even spiritual revolution. They did not want an early election that might halt their transformational project, a point regularly negatively expressed by saying, as the Catholic Archbishop did, that elections 'would not halt Fiji's coup culture'. Perhaps not, replied lawyer Richard Naidu, ridiculing the idea that a military-sponsored initiative like the NCBBF might serve this purpose. Elections were a means to an end, said Naidu, not a panacea for all Fiji's difficulties. The key and fairly obvious point was that only a constitutional government could find long-term solutions to Fiji's 'coup culture'. $^{125}$ Naidu, like many of the public opponents of the coup, had been harassed at the Queen Elizabeth Barracks after the coup, when soldiers fired off a gun next to his hooded head, before releasing their traumatized captive. He, like many others, lowered his profile, and adopted a more cautious public stance. Despite all this harassment, when supporters and opponents of the 'People's Charter' came together in a public debate in Suva's JJs on the Park banquet hall, it was clear that the intellectual heavyweights - including Richard Naidu, Wadan Narsey and Tupou Draunidalo - were on the opposing side. ${ }^{126}$ That the middle ground had shifted away from a strained participation in the NCBBF initiative (on the grounds of the need for dialogue) was indicated by the resignations of Daryl Tarte, Mick Beddoes and Suliana Siwatibau in early 2008. Even amongst 
the Indian community, whose leader was in cabinet, the longer-term political ramifications of the coup were, by mid-2008, increasingly uncertain. As a Fiji Times editorial noted in April 2008 'there has been no groundswell of support for Commodore Bainimarama'. ${ }^{127}$

Overseas pressure on Fiji's interim government to hold elections was often justified in the context of broad-ranging principles of human rights or democratic norms. In response, Bainimarama's ministers regularly upbraided foreign diplomats for a 'dogmatic' focus on the election timetable, and pleaded greater familiarity with Fiji's historical circumstances. ${ }^{128}$ The weight of domestic hostility to the coup, silenced by civil rights abuses, ongoing intimidation and some growing sense of fatalism, was increasingly forgotten or conveniently ignored in this post-coup dialogue, even amongst those overseas commentators who were familiar with the once open style of pre-coup Fiji politics. But diplomatic pressure for an election or for a restoration of constitutional democracy only made good sense as a means for externally articulating the robust - if intimidated and sometimes silenced - Fiji-based resistance. Bainimarama's decision to repudiate the March 2009 election date did not reflect some heartfelt commitment to the grand cause of electoral reform, but was rather a pragmatic acknowledgement of the unpropitious domestic balance of social forces.

\section{ENDNOTES}

1 Commander RFMF - Public Declaration of Military Takeover, 5 December 2006.

2 Sukuna, Ratu Sir Lala, Fiji: The three-legged stool; selected writings of Ratu Sir Lala Sukuna, (ed) Scarr, D., London: Macmillan, 1983.

3 'Fijian Affairs (Great Council of Chiefs) Regulations 2008', Republic of Fiji Islands Government Gazette, 8 (12), 13 February 2008.

4 Fijilive, 7 December 2006.

${ }^{5}$ H.E. the President's speech after the commander handed back authority, 5 January, 2007.

6 'Interim Government May Rule for Five Years', PacNews, 23 January 2007.

7 'Chiefs want early Polls', The Fiji Times, 30 March 2007; Churches want early return to democracy', fijilive, 13 June 2007.

8 The Millbrook Commonwealth Action Programme on the Harare Declaration, 1995, available http://www.thecommonwealth.org/Internal/20723/34458/the_millbrook_commonwealth_action_programme/; see also the comments of Secretary General Don McKinnon cited in The Fiji Times, 22 October 2007; The Guardian, 8 December 2006.

${ }^{9}$ Shaista Shameem, Director, Fiji Human Rights Commission, 'The Assumption of Executive Authority on December $5^{\text {th }}$ by Commodore J.V. Bainimarama, Commander of the Republic of Fiji Military Forces: Legal, Constitutional and Human Rights Issues', 3 January 2007, http://www.humanrights.org.fj.

10 See for example, 'Commander RFMF's Handover Speech', 4 January, 2007. On the reasons for the pre-2006 election Constituency Boundaries Commission not revising district boundaries, see Kesaia Seniloli, 'Fiji's electoral boundaries and malapportionment', in Fraenkel and Firth, From Election to Coup in Fiji; The 2006 Campaign and its Aftermath, Institute of Pacific Studies, Suva, and Asia-Pacific Press, Canberra, 2007, pp. 288-299.

${ }^{11}$ Australia suspended the defence cooperation program and parts of the law and justice sector program (ie. assistance to the security services), but health and education programs continued. New bilateral initiatives were also suspended, aside from programs aimed at facilitating an early return to democracy. 12 See 'Fiji-EU Diplomacy', Oceania Flash, 19 April 2007; The Fiji Times, 20 April 2007; and 'Fiji's Cooperation with EU Vital', fijilive, 22 June 2007. Commitments to the EU had included 'the staging of 
free and fair parliamentary elections within 24 months from March 1, 2007' ('Election before Aid', The Fiji Times, 2 October 2007).

13 Pacific Islands Forum, Press Statement, 24 January 2007.

14 Forum Eminent Person's Group Report on Fiji, 29 January-1 February, 2007, available http://forumsec.org/_resources/article/files/FIJ\%20EPG\%20REPORT,\%2029\%20Jan\%20to\%201\%20Feb\%2020071.pdf. 15 Fiji Government Submission to the Forum Foreign Affairs Meeting on the EPG Report on Fiji, $16^{\text {th }}$ March 2007, Ministry of Foreign Affairs and External Trade.

16 'Roadmap of Interim Government', The Fiji Times, 21 February 2007.

17 See, for example, Narsey, this volume.

18 'FLP widens racial gap', The Fiji Times, 11February 2008. The announcement regarding the downgrading of the ministry of Fijian affairs (http://www.fiji.gov.fj/publish/printer_10683.shtml), was subsequently reversed ('Fijian Affairs not downgraded - PM Bainimarama',

26 November 2007, http://www.fiji.gov.fj/publish/page_10688.shtml).

19 'Labour will not Withdraw from Regime', The Fiji Times, 12 February 2008.

20 Large sums of money obtained by Chaudhry from India in the wake of the 2000 coup had been placed in Australian bank accounts (see Victor Lal, 'Chaudhry Letter Reveals Hidden Donations', Fiji Sun, 25 February 2008). Speaking before parliament in 2005, Chaudhry had denied knowledge of these payments (see http://www.parliament.gov.fj/hansard/viewhansard.aspx?hansardID=441\&viewtype=full). Under investigation by the Fiji Islands Revenue and Customs Authority (FIRCA), he had produced a letter from a man in India claiming that these payments were to assist the deposed prime minister to relocate his family in the wake of the 2000 coup. An enquiry by Bainimarama's interim government found that FIRCA had conducted its enquiries on the matter properly, but did not address the issue of whether Chaudhry had misled Fiji's parliament in 2005. It also accepted Chaudhry's claim that he was unaware of FIRCA procedures for handling interest payments on overseas interest earnings, although it seemed rather unlikely that the finance minister in the 1987, 1999-2000 and post-2006 coup interim governments would be unaware of these provisions. The other remaining mystery was whether those funds were, as claimed, for personal use or whether they had been intended to assist the beleaguered Fiji Indians suffering in the wake of George Speight's takeover in 2000.

21 'We are ready to assist: Australia', fijilive, 7 June 2007.

22 'Fiji elections "in 2008 possible"', fijilive, 7 June 2007.

23 'Fiji Cabinet "agrees" to 2009 election', fijilive, 19 June 2007.

24 'Australia welcomes Fiji's stand on elections', fijilive, 20 June 2007. Australia provided \$437,000 for the 2007 census ('Aussies keen to help commission', The Fiji Times, 16 January 2008)

25 'Fiji's cooperation with EU vital', fijilive, 22 June 2007.

26 'Australia worried by Bainimarama's comments', fijilive, 1 June 2007; 'Chaudhry reveals election date to India', The Fiji Times, 22 May 2007.

27 'Clark says Fiji playing for time', The Fiji Times, 21 June 2007.

28 'Critics put Elections in Limbo', fijilive, 3 July 2007.

29 'NZ “hell bent” on hurting Fiji: interim PM', fijilive, 3 July 2007.

30 'We have no voters to please: Bainimarama', The Fiji Times 3 August 2007.

31 'Bainimarama: strike could defer poll', The Fiji Times, 1 August 2007.

32 See, for example, the commander's eulogy to the new multi-party government after the 2006 polls in Mataivalu News, July/August 2006, p.3; see also 'Fiji military pledges support for government', The Fiji Times, 28 July 2006.

33 'Army to release more Foster videos', fijilive, 3 January 2007.

34 The Fiji Times, 9 May 2007.

35 The Fiji Times, 11 May 2007

36 Fijivillage, 16 December 2006.

37 'Coup a revolution, says Vayeshnoi', fijilive, 25 June 2007.

38 By-elections in Tavua and Cakaudrove prior to the May 2006 polls had suggested that the forthcoming general election would be sharply polarized, although no one then said those had been rigged. The acutely ethnically polarized political temperature throughout 2001-06 - inflamed particularly by conflict between Qarase and Chaudhry over the multiparty cabinet provisions, the Promotion of Reconciliation, Tolerance and Unity Bill, and the treatment of 2000 coup convicts - made the 2006 election outcome 
likely to be highly divided. Based on projections giving $80 \%$ of the Fijian vote to the SDL and $80 \%$ of the Indian vote to the FLP, the overall election results were reasonably straightforward to predict. Once the political parties released their rankings for redistribution of preference votes for each of the 71 constituencies, those predictions could be fine-tuned to anticipate results for each constituency. I conducted several workshops for diplomats and for the media in August and October 2005 and March 2006, explaining this methodology for predicting the 2006 electoral outcomes ('Alternative Scenarios at the Forthcoming Polls', Understanding the Next Fiji Elections; A Workshop for Diplomats, Tanoa Plaza, Suva, Fiji, 15 August 2005; 'Analysing Fiji Elections', Media and Elections Workshop, Suva, 20-22 March 2006; 'Understanding the Alternative Vote System; Preference Exchange, the Count Process and Getting from Votes to Seats', 2006 Fiji Media and Elections Workshop, Tanoa Plaza, Suva, Fiji, October 22 2005). As the international observer teams arrived, I publicly briefed both the PIF and EU observers again explaining that methodology ('Briefing Presentation for Combined International Observers to the Fiji 2006 election, Police Academy, Nasese, Suva, April 2006; Briefing Presentation for Pacific Islands Forum Election Observers, Fale, Pacific Islands Forum Secretariat, Ratu Sukuna Road, Suva, April 2006). Other observers also predicted an outcome that was close to the final result, with FM96's Yellow Bucket column calling every seat except one correctly.

39 Chaudhry, M. 'Tainted elections', in Fraenkel and Firth, From Election to Coup in Fiji; The 2006 Campaign and its Aftermath, Institute of Pacific Studies, Suva, and Asia-Pacific Press, Canberra, 2007, pp 347-364.

40 In one case - Nadi Open - the result was overturned by Justice Anthony Gates giving victory to the FLP candidate. The Court of Appeal concluded that he had made a serious mistake in law.

41 One indication of the temperature of allegations of fraud was the CCF's ElectionWatch workshops. I attended both the 2001 and 2006 workshops. In 2001, the audience was packed, and allegations of irregularities and malpractice were wild and furious - although most turned out to be bogus. In 2006, the audience was much smaller and there were few allegations of fraud.

42 A letter from Minister of Public Works and Energy Joketani Cokanasiga to Prime Minister Qarase, dated 8 August 2001, described a decision by the finance ministry to suspend the agricultural assistance scheme so soon before the general election as 'political suicide'. The origins of this program were in fact prior to the 2001 election announcement: it was aimed at placating discontent in rural Fijians areas in order to avoid any repeat of the Speight uprising, as were nearly all of the initiatives of the Qarase government.

43 Fiji Human Rights Commission, 'Report of the Commission of Inquiry into the Fiji 2006 General Elections', September 2007.

44 David Arms, 'A Critique of the Report of the Independent Assessment of the Electoral Process in Fiji', 31 July 2007, included as an annex to the main report.

${ }^{45}$ Fiji Human Rights Commission, 'Report of the Commission of Inquiry into the Fiji 2006 General Elections', September 2007, p23.

46 'Commentary on the SDL's Response to the Draft Report', annex to Fiji Human Rights Commission, 'Report of the Commission of Inquiry into the Fiji 2006 General Elections', September 2007.

47 Report of the Commission of Inquiry into the Fiji 2006 General Elections, Fiji Human Rights Commission, September 2007, pp.5, p9-10; see also David Neilson 'What if the Fiji ballot was less than "Free and fair"?', New Zealand Herald, 15 October, 2007.

48 Unlike the Commission, I can offer detailed first-hand evidence of this. I was a University of the South Pacific election observer during the 2006 election. Early in election week, the problem of officials finding the names of voters on one roll, but not on the other, became apparent and much discussed. I personally raised this with the Fiji Elections Office, and was told that - although the colour-coded registration slips handed out to voters at the time of registration were often in error, the electoral rolls themselves were not. Over the following days of election week, I tested this claim by requesting presiding officers in the polling stations to show me their logbook records of voters who had been able to cast only one vote because their name could not be found in a corresponding open or communal constituency. In every case I checked, the Elections Office was correct: it was possible for presiding officers, if they ignored the registration slips, to use any one correct entry on the electoral roll to find the other. In other words, the problem lay with the registration officials and with the training of polling station officials. It was not an indication of systemic bias or ballot-rigging. In any case, during the final days of election week, in somewhat chaotic circumstances, the Fiji Elections Office effectively dispensed with the electoral rolls as a means of avoiding duplicate voting and allowed citizens whose name was found on one roll to cast a second vote on a corresponding open or communal roll, even if their name could 
not be found. From that point, prevention of duplicate voting depended solely on reference to the ink marked on voters' fingers.

49 The same confusion of registration slips with the actual entries on the rolls is repeated in Dr Neilson's New Zealand Herald article: 'The recurring experience among Indian voters in [urban, open] constituencies in particular was of correct registration in the communal constituency and mis-registration in the open constituency' (David Neilson 'What if the Fiji Ballot was less than "Free and fair"?', New Zealand Herald, 15 October, 2007).

50 If the Commission had instead chosen to follow up on Fr David Arms comment about the election outcome being decided in key marginal open constituencies around the Suva-Nausori corridor in the Central Division in 2001 and 2006 and the logical likelihood that any ballot-rigging would target these constituencies, they might have noticed that all of the tabulation forms (O-38s and O-39s) had suspiciously disappeared for these key constituencies both in 2001 and 2006, despite firm assurances before the 2006 polls from both the supervisor and the chairman of the Electoral Commission that they would order their release (these assurances were likely to have been genuine, I believe, because the Supervisor's office successfully obtained every other one of these forms for the Eastern, Western and Northern Divisions). With these O-38 and O-39 tabulation forms an expert eye, such as that of Fr Arms, might well have been able to detect any odd movements of preference votes that suggested resort to ballot-rigging. Most likely, the real reason why these forms were concealed in 2001 and 2006 was that they were a hideous mess, smothered in tipex and full of errors, and the Commissioner Central did not want expert eyes scrutinizing the way they had been completed. The Central Division, covering the Suva-Nausori corridor, covers the vast majority of the close-to-parity Fijian/Indian constituencies and therefore tends to have many more successive counts than other divisions, rendering tabulation particularly problematic. The Commissioner Central, Inoke Devo, was arrested under the post-coup government, and convicted on charges of corruption in issuing liquor licenses, but notably not for his role as Chief Returning Officer in the Central Division.

51 Statement of the Prime Minister of Fiji to the 62nd session of the United Nations General Assembly., New York, 28 September 2007, p.4.

52 Bainimarama, speech to UN, cited 'Fiji: Interim PM outlines plans for referendum', Radio Australia 2 October 2007.

53 'Rumblings of a revolution', Sydney Morning Herald, 27 October 2007.

54 See Morgan Tuimaleali'ifano, 'Indigenous title disputes: what they meant for the 2006 election', in Fraenkel and Firth, From Election to Coup in Fiji; The 2006 Campaign and its Aftermath, Institute of Pacific Studies, Suva, and Asia-Pacific Press, Canberra, 2007, pp. 261-271

55 See Yellow Bucket, 'The failure of the moderates', in Fraenkel and Firth, From Election to Coup in Fiji; The 2006 Campaign and its Aftermath, Institute of Pacific Studies, Suva, and Asia-Pacific Press, Canberra, 2007, pp. 108-9.

56 For details, see Jon Fraenkel, 'The Triumph of the Non-Idealist Intellectuals? An Investigation of Fiji's 1999 Election Results', Australian Journal of Politics and History (46), 1, 2000, pp. 93-95.

57 Radio New Zealand, 7 December 2006.

58 See Jonathon Prasad, 'The role of Hindu and Muslim religious organizations during the 2006 election', in Fraenkel and Firth, From Election to Coup in Fiji; The 2006 Campaign and its Aftermath, Institute of Pacific Studies, Suva, and Asia-Pacific Press, Canberra, 2007, pp. 315-336.

59 'Sanctions on Fiji to stay', fijilive, 18 October 2007.

60 “"Don't let up on sanctions" deposed Fiji PM tells New Zealand', New Zealand Herald, 18 October 2007.

61 'Interim PM says he is not power hungry', Fijivillage, 18 October 2007.

62 'EU Considers Fiji Aid', fijilive, 11 September 2007.

63 See, for example, 'Police Disallows Political Party Meeting', fijilive, 27 July 2007.

64 'No polls if we're not ready', Fiji Post, 9 October 2007.

65 See http://eur-lex.europa.eu/LexUriServ/site/en/oj/2007/1_260/1_26020071005en00150020.pdf ; ‘EU Concerned with Lack of progress', The Fiji Times, 9 October 2007; 'EU Suspends Sugar Industry Assistance', Radio Australia, 9 October 2007

66 'PM Convinced EU will provide funds', The Fiji Times, 10 October 2007.

67 http://www.forumsec.org/_resources/article/files/2007\%20Forum \%20Communique, $\%$ 20Vava'u \% 20-\%20Final\%20Version.pdf.

68 'Constitution talk rocks Pacific Forum', New Zealand Herald, 19 October 2007. 
69 'People's Charter will not allow Qarase to contest next election: Bainimarama', The Fiji Times, 18 October 2007; 'Fijian coup leader sets deadline for election', Sydney Morning Herald, 18 October 2007. 70 'Downer, Clarke welcome 2009 Fiji poll' Fijilive 18 October 2007.

71 See, for example, 'Time less important: CCF', Daily Post, 21 June 2007; Aisake Casimira, in The Fiji Times 26 February 2007.

72 'Aust/NZ Trying to Bully Fiji: FLP', Fijilive, 18 October 2007.

73 'Poll won't end coups: Mataca', The Fiji Times, 18 January 2008.

74 Akuila Yabaki, 'Military must back off on charter', The Fiji Times, 22 October 2007; 'Parties attempt to derail charter', Fiji Times, 1 February 2008.

75 'Fiji council positions to remain open', fijilive, 17 January 2008.

76 'Frankly Speaking with Voreqe', Sunday Times, 21 October 2007

77 'People will have final say on what is in Charter', The Fiji Times, 16 February 2008.

78 'Academic Refers to Charter as Sacred', The Fiji Times, 21 June 2008.

79 'Charter similar to 1987 military list: Savua', fijilive, 31 March 2008.

80 'Qarase Choice “was a Mistake”', The Fiji Times 20 September 2007.

81 'Frankly Speaking with Voreqe', Sunday Times, 21 October 2007

82 'Latest Fiji Constituency Boundaries Commission chair accepts she is ruled out', Radio New Zealand International, 25 October, 2007.

83 'Judge Scutt's words shocks law society', Fiji Daily Post, 7 February 2008.

84 'NZ lawyer withdraws as Fiji election supervisor', Radio Australia, 22 April 2008.

85 'The Constitution for the Party', The Fiji Times, 31 May 2008.

86 'Poll in 2009, says Interim PM', The Fiji Times, 5 June 2008.

87 'The Constitution for the Party', The Fiji Times, 31 May 2008 [emphasis added].

88 'Fiji's problems are Deep-Rooted, Says Commodore Bainimarama', The Fiji Times, 31 May 2008.

89 'Fiji Regime Backs Forum Move', fijilive, 17 April 2008.

90 'Who's Right and Who's Wrong', Fiji Daily Post, 29 May 2008.

91 'Elections ASAP in 2009: Fiji PM', fijilive, 13 May 2008.

92 'No Charter, No Election', The Fiji Times, 23 May 2008.

93 'Timely Election Reminder', The Fiji Times, 14 May 2008

94 The Fiji Times, 5 April 2008.

95 'Chaudhry: Charter ready by August', The Fiji Times, 13 February 2008.

96 John Samy, 'The Aftermath of 1987', Fiji Daily Post, 11 June 2008.

97 Altering the Electoral System', Fiji Sun, 4 March 2008.

98 'Rumblings of a revolution', Sydney Morning Herald, 27 October 2007.

99 'Ministers "Fail to Address Problems"' The Fiji Times, 5 April 2008.

100 NCBBF Communique, 24 June 2008,

http://www.fijilive.com/archive/showpdf.php?pdf=2008/07/COMMUNIQUE\%20NCBBF\%2024.6.08.pdf; see also 'Plan to Change Voting System', Fiji Sun, 24 June 2008.

101 I have long supported adoption of a common roll system in Fiji, despite disagreement with those scholars who attribute race-based voting to use of communal rolls, see Jon Fraenkel, 'The Triumph of the Non-Idealist Intellectuals? An Investigation of Fiji's 1999 Election Results', Australian Journal of Politics and History (46), 1, 2000.

102 This historical background is discussed at greater length in Jon Fraenkel, 'Electoral Engineering and the Politicisation of Ethnic Frictions in Fiji', Bastian, S and Luckham, R (eds) Can Democracy be Designed? The Politics of Institutional Choice in Conflict-Torn Societies, IDS, Sussex, Zed Books Ltd, 2003, pp220-252.

103 In communal contests, citizens were denied the opportunity to cast votes for parties primarily rooted in the other group. The often heard broader claims about communal constituencies causing race-based voting have never been substantiated through any solid empirical analysis.

104 The 'cross-voting' or 'national' seats during 1965-1987 were common roll, although the ethnicity of the candidates was specified. 
105 Chaudhry, cited in Brij Lal, Another Way; The Politics of Constitutional Reform in Post-Coup Fiji, NCDS/Asia-Pacific Press, 1998, p. 96.

106 The only examples of this might be Ofa Duncan (Swann)'s victory in Lami open for the United People's Party in 1999 and for the New Labour Unity Party in 2001.

107 For a global survey of the use of reserved constituencies, see Andrew Reynolds. 'Reserved Seats in National Legislatures: A Comparative Approach' in Comparative Redistricting, (ed) Lisa Handley, Oxford University Press, 2008. Other countries also have a 'general roll' as well as rolls for minorities, but nowhere else on the globe has two large ethnic groups on separate ethnic rolls with 'generals' as a minority.

108 See Sydney Elliot 'North vote sees over 80 per cent of transfers stay within main parties', Irish Times, 1 December 2003.

109 Perry Mars, 'Ethnic Politics, Mediation, and Conflict Resolution: The Guyana Experience', Journal of Peace Research, 38, (3), 2001, pp. 357359.

110 List proportional representation is a system designed to ensure that party seat shares in parliament are reasonably close to party vote shares. The system always uses multi-member constituencies, and voters simply tick the ballot to indicate their support for a party list. Under 'closed list' systems, the party determines which of its candidates get elected. Under 'open list' systems, the voter can indicate choice of both candidate and party.

111 'Beddoes Slates Clergy's Proposal', fijilive, 6 June 2006

112 'Chiefs Point to Need for Dialogue', fijilive, 14 June 2008.

113 See Qarase, 'Fiji's system of elections and government: where to from here?', in Fraenkel and Firth, From Election to Coup in Fiji; The 2006 Campaign and its Aftermath, Institute of Pacific Studies, Suva, and Asia-Pacific Press, Canberra, 2007, pp. 343, 346.

114 Press Release from Ro Filipe Tuisawau, reproduced on the website Solivakasama, 16 April 2008.

115 'Qarase offers to resign if SDL plan accepted', fijilive, 24 November 2007.

116 'Don't tell us how to do it: PM', fijilive, 24 November 2007.

117 'Talks held with Sir Paul in secret', The Fiji Times, 13 December 2007

118 'Qarase brushes off invitation', The Fiji Times, 9 June 2008

119 'PM Sends Word To Sevele', The Fiji Times, 24 June 2008.

120 'Stop Being Obsessed with Poll Timelines', The Fiji Times, 20 June 2008; 'Beddoes Hails EU Input', The Fiji Times, 23 June 2008

121 'EU Mission', Fiji TV News, 14 July 2008.

122 '2009 election unachievable: Interim PM, The Fiji Times, 18 July 2008.

123 'Genuine efforts led to flexibility: Dr Sevele', The Fiji Times, 19 July 2008.

124 'Former interim minister sheds light on Cabinet discussions', Fiji TV, 9 April 2008.

125 Richard Naidu, speech at the Fiji Media Council Forum - A Debate: “The People's Charter for Change, Peace and Progress is good for Fiji.", JJ's On the Park Banquet Hall, 10 April 2008.

126 The speeches were reproduced on the The Fiji Times website, http://www.fijitimes.com/peoples-charter-debate.aspx.

127 'Electoral Reality', Editorial, The Fiji Times, 18 April 2008.

128 Aiyaz Sayed-Khaiyum, cited in 'Fiji accuses Australia and NZ of being dogmatic', Radio New Zealand International, 29 June 2008. 